\title{
THE EFFECT OF ALOE VERA GEL ON PHLEBITIS AMONG IN-PATIENTS
}

\author{
Binarti Dwi Wahyuningsi ${ }^{1)}$, Amar Akbar ${ }^{2)}$ \\ 1) Department of Psychiatric Nursing, \\ School of Nursing (AKPER) Bina Sehat PPNI \\ 2) Department of Medical and Surgical Nursing, \\ School of Nursing (AKPER) Bina Sehat PPNI
}

\begin{abstract}
BACKGROUND: Phlebitis may cause thrombus, emboli, and infection. Aloe vera has more than 75 potentially active components, including vitamins, minerals, saccharides, amino acids, anthraquinones, enzymes, lignin, saponins, and salicylic acids. Aloe gel has been used as a remedy for skin conditions, including burns, sunburn, frostbite, psoriasis and cold sores. It has also been used for treating osteoarthritis, bowel diseases, fever, itching and inflammation. This study aimed to examine the effect of aloe vera gel to reduced phlebitis among in-patients.

SUBJECT AND METHODS: This was a quasi-experimental study using pre and post one group. A sample of 19 patients with phlebitis was selected from Wahidin Sudiro Husodo Hospital, Mojokerto, East Java. The dependent variable was phlebitis, measured by Phlebitis Scale (from the Infusion Nursing Standards of Practice 2011 S47): (1) Grade o = no symptoms; (2) Grade 1 = erythema at access site with or without pain; (3) Grade 2 = pain at access site with erythema and/or edema; (4) Grade $3=$ pain at access site with erythema and/or edema, streak formation, palpable venous cord; and (5) Grade 4 = pain at access site with erythema and/or edema, streak formation, palpable venous cord greater than 1 in in length; purulent drainage. The independent variable was aloe vera gel. The data were analyzed by Wilcoxon test.

RESULTS: Phlebitis grade decreased significantly from mean $=3.60$ before aloe vera treatment to mean $=1.20$ after aloe vera treatment $(\mathrm{p}=0.001)$.
\end{abstract}

CONCLUSION: Aloe vera treatment can be used to reduce phlebitis.

Keywords: phlebitis, aloe vera 